\title{
China and India as Emerging Global Governance Actors: Challenges for Developing and Developed Countries
}

\section{John Humphrey and Dirk Messner}

\section{Introduction}

The debate on global governance that intensified at the end of the Cold War reflected the recognition that accelerating globalisation was creating crossborder and global problems that could not be solved within the ambit of nation states pursuing go-italone policies. Rather, these problems needed to be tackled politically on the basis of new forms of 'governance beyond the nation state' (Zürn 1998; Rosenau 1997; Nye and Donahue 2000; Kennedy et al. 2002). International financial crises, banking regulation, global climate change, international property rights, migration flows, humanitarian interventions and the fight against transnational terrorism have increasingly become the objects of global policy processes, along with continued concern with long-established questions such as the international trade regime.

The purpose and goals of global governance are defined against this background as the 'development of a system of institutions and rules as well as of new mechanisms of international cooperation that make it possible to deal on a continuous basis with the problems posed by global challenges and transboundary phenomena' (Messner 2000: 284). The main aim of global governance is to avoid crises and turbulence within the global system, with an increasing range of issues seen as potentially threatening. But global governance amounts to more than this: it also has developmental objectives. For much of the 1990s, these were framed as a neoliberal policy agenda aimed at promoting faster economic growth through internal and external liberalisation. Increasing global integration was seen as a positive factor for economic growth (World Bank 2002), although the increasing salience of discussions addressing issues such as "managing globalisation" or "making globalisation work for the poor" indicated a perception that globalisation processes would need to be managed politically if they were to promote inclusive development. ${ }^{1}$

The global governance discourse of the 1990s was geared to strengthening a multilateral world order and creating new patterns of cooperation between governmental and private actors. Indeed, this was the period in which corporations and nongovernmental organisations (NGOs) became more prominent in global governance. Private and publicprivate organisations became more important in a variety of global governance institutions, and in particular in standards setting around finance, trade, labour and the environment (Nadvi and Wältring 2004). Scholte (2000: 151) refers to the trend of private sector actors playing an increasing role in regulatory activities at the global level as the "privatisation of governing". ${ }^{2}$

Nevertheless, the emergence of a multi-actor, multilevel global governance system did not appear to create space for effective participation by developing countries in global governance institutions (Rodrik 1997; Maggi and Messner 2002). The limited participation and influence of developing countries in global governance institutions is often remarked upon. Even in trade negotiations, which have provided many opportunities for developing countries to develop understanding and capabilities, the most decisive indication of developing country capacity to frame agendas and stake out positions occurred

IDS Bulletin Vol 37 No 1 January 2006 (C) Institute of Development Studies 
as recently as the negotiations leading up to the Doha Round. Similarly analyses of developing country participation in the many fora that define and apply the technical rules that have such an important impact on trade frequently point to the limited participation of developing countries. ${ }^{3}$ In this context, one concern of policy-makers has been to enhance the participation of developing countries in such fora through the training for negotiators and technical staff and supporting participation in meetings.

The marginalisation of developing countries in global fora was exacerbated by the events of 11 September 2001, which shifted the focus of the discussion to the future of world politics under the conditions of globalisation. The responses of the US administration to the attacks in New York and Washington and the Iraq war have provoked an intensive discussion over the unilateral world order in the shadow of the "lone superpower" (Cooper 2003; Daalder and Lindsay 2004; Mead 2004). Many observers have argued that the US will be the only global superpower for some time to come. Apart from the US, it is claimed, there is no other actor in sight that could exert a comprehensive and sustained influence on global governance processes (Kagan 2003). If this were true, the developing countries would no longer have a role to play as effective actors in international politics and global governance.

And yet, at the moment when discussion over the "unilateral world order" reaches its peak, a new debate emerges. This focuses in particular on the rising power of China and India, as well as a number of other "anchor countries" like Brazil and South Africa (Goldman Sachs 2003; Stamm 2004; Friedman 2005), and it draws our attention to a new challenge to the global hegemony - of the US in particular - of the industrially advanced economies in general.

\section{The new power constellation}

The "new Asian Drivers of global change" are becoming global players who are forcefully altering the relationship between industrialised and developing countries. The rise of China and India as both economic and political actors is having, and will have, significant and far-reaching impacts. While India is not so prominent in world trade and finance as China, it has shown sustained growth for two decades and has good prospects for sustained growth over the next decade (Rodrik and Subramanian 2004: 3; Deutsche Bank Research
2005). By 2020 it is likely to be the world's third largest economy. It is playing an increasing role in global governance institutions and in leadership among developing countries. China's impact on the global economy has been more visible. Its share of total US imports rose from 6 per cent in 1995 to 15 per cent in 2004, ${ }^{4}$ the Organisation for Economic Co-operation and Development's (OECD) Economic Survey of China (published in September 2005) predicts that it will overtake Germany and the US to become the world's largest exporter by 2010 ; China's share of the world demand for key base metals has risen from 5-7 per cent in the early 1990s to 20-25 per cent at present; it holds the world's second largest currency reserves, amounting to over US\$670bn; and China will soon be catching up with the world's largest $\mathrm{CO}_{2}$ emitters, on whose future energy policies the dynamics of global climate change will hinge in very crucial ways.

The rise of India and China as significant actors for global governance and the world economy will transform today's "quasi-unilateral world order" into a de facto multipolar power constellation. By 2025-30 at the latest, the US, China, India and possibly Europe will constitute four substantial poles of power in the architecture of global governance. The future interplay among these central actors of global governance will largely determine whether and how the transboundary and global problems of the twenty-first century are dealt with and what role the world's developing regions will be able to play in world politics and the world economy. This new multipolar power constellation and the competition for power and policy options resulting from it will become the central line of conflict shaping the architecture of global governance in the coming five decades - in ways much like the system conflict that dominated during the Cold War or the endless conflicts between the Central European powers in the era leading up to the World War I. The future will be shaped by "turbulent multilateralism".

The emergence of China and India as powerful actors in global governance arenas and in global politics poses a series of questions for development policy and the future of global governance. In this short article, we highlight three areas in which this challenge will be felt:

- By the governments of the industrialised countries as China and India offer development alternatives 
- For the governability of global governance institutions in a period of multipolar power constellations

- By developing countries seeking to prosper in a period of turbulence and change induced by the "Asian Drivers of Global Change".

\section{Challenges for the industrialised world}

The current rise of China and India means that two non-Western countries are becoming weighty actors in the global system. ${ }^{5}$ How will the "West" deal with this state of affairs, particularly given the fact that these two non-Western societies are home to more than one-third of the world's population? Charles Kupchan, a member of the US Council on Foreign Relations and an important policy adviser of the Clinton administration, may have asserted that "Globalization is Americanization" (Kupchan 2002: 72; emphasis in original), but for how much longer? And how long will Western countries need to understand that this coincidence of interests and power, for years beyond question, might soon become a thing of the past? For the development policies of the advanced nations, based on a consensus of Western nations, China and India pose big challenges.

One might argue that the rise of China, in particular, presents a challenge to the development project of the Western nations, inspired as it has been by predominantly Christian ideals transmuted into a secular ideology of human rights and poverty reduction. Perhaps for the first time since the 1960s and the heyday of Soviet influence in developing countries, there is the possibility of an alternative view of what development is and how to achieve it. The "Beijing Consensus" (Ramo 2005) is one expression of this, but not the only one. Kurlantzick (2005: 28) observes that China is "challenging US 'soft power' - the combination of economic vitality, cultural pull, trade and diplomacy that, as much as military force, has made the US the pre-eminent force in the world". He argues that this is particularly the case in Asia.

The rise of China means the rise of an undemocratic, non-liberal state in both the world economy and in the hierarchy of global governance, although China may well have to deal with pressures for democratisation in the coming years. This may pose problems for the legitimacy of global governance processes, which of course depend not least on the legitimacy of the significant actors that shape them. Will binding worldwide human rights, social and environmental standards prove even more difficult to implement and entrench in the altered context of global governance? For example, how vulnerable are efforts undertaken in the framework of international development cooperation and aimed at advancing democracy and conflict prevention to targeted attempts to undercut them? China's close cooperation and investments in countries with poor human rights records - Zimbabwe, Sudan, Algeria (Alden 2005) - and its close energy partnership with Iran seem to point to some potential lines of conflict. It can at the same time be observed that the "Chinese model" (authoritarian political regime/market economy) might find some admirers in Africa and Latin America.

In this respect, the potential posture of China in global governance is particularly important, as are the internal political dynamics that might shape this posture. In many respects, China assumes the posture of a great power, and it has challenged some of the core tenets of international development thinking. It has become markedly more active in the security field, providing policing support in Haiti, and peacekeeping troops in Liberia since 2003. It has expressed support for Myanmar and the Sudan in spite of their poor human rights records. It has developed more active relationships with numerous African and Latin American states, partly because of its economic interests but above all for access to raw materials for its booming economy. It has also been more assertive in geopolitics, staking out positions within the UN on the future of Iraq. The West will have to learn to interact with new global powers possessing growing self-confidence.

More generally, the rise of India and China presents problems of leverage and influence for Western donors. Western countries have limited leverage on China and India. They provide little foreign aid, and while China and India need close cooperation with the western countries in areas like innovation, technology and environmental policies, which implies interdependency, Western countries also need access to fast-growing markets and competitive centres of production and innovation. The challenge for developed countries is to work with self-confident and often demanding partners who cannot be coerced through financial power. 
This leverage (or lack of it) question will be felt by Western countries as India and China assume more active roles in global development policy and in aid. ${ }^{6}$ They may compete with Western governments for influence, particularly when competing for scarce resources, as is being seen in the geopolitics of resources where China, in particular, but also India, are seeking cooperation with developing countries (Venezuela, Sudan, Iran: energy; Latin America: agricultural products; Africa: natural resources).

\section{Challenges for institutions of global governance}

The thinking of the relevant political actors in China and India is largely dominated by classic concepts of sovereignty and the nation state, even though both countries are fond of making use of multilateral rhetoric. In comparison, decision-makers in the industrialised countries, and Europe in particular, have learnt in the context of ongoing globalisation debates, global interdependencies and the limits on the scope for national action that delegation of sovereignty, for example to the $\mathrm{EU}$, the use of international cooperation to focus their national governance resources, and a modified understanding of the concept of "non-intervention" (e.g. in cases involving human rights protection vs. noninterference in internal affairs) are necessary responses for maintaining the action and problemsolving capacities of politics in a globalised world. Interestingly, the classic understanding of sovereignty and the nation state subscribed to by China and India coincides fully with the political thinking of the present US administration. Viewed against this background, it is easy to understand why China and India, in the summer of 2005, signed on to the Bush administration's "climate initiative", which is clearly aimed at undercutting the multilateral Kyoto process and the ongoing efforts to set clear-cut upper limits for $\mathrm{CO}_{2}$ emissions. Should these basic political patterns solidify in the US, China and India, this would have major implications for the dynamics of future global governance processes.

Further, even if the world economy reaches a new configuration, history shows that the adjustment pressure outlined above will give rise to turbulent instabilities in the phase of transition to a multipolar power constellation. One conceivable scenario would include big-power rivalries between the established superpower and the new, rising powers.
When, during the Asia crisis of 1997-8, Japan broached the subject of creating an Asian bank mandated to stabilise currencies there, Washington promptly let it be known that the IMF would take care of the matter. What will happen when China and India one day start to develop global governance strategies of their own? Who is to mitigate these instabilities, to moderate them and direct them into cooperative channels? Will the US, today's lone superpower, prove to be up to this challenge? Could Europe assume this role, or will it continue to be concerned mainly with its own internal affairs?

China and India's new-found willingness to play global roles will create new challenges for global governance and governance institutions. China has in recent years been pursuing clearly discernible regional strategies in Asia, Africa and Latin America. These appear to be geared chiefly to securing its supply of raw materials and energy. These processes are altering the global markets for raw materials and energy. India too has been playing an increasingly proactive role in the fields of climate policy and world trade. In other words, the processes outlined above are generating adjustment pressure in the architecture of global governance, giving rise to new constellations of actors and power. Can anyone even conceive that in the year 2030 , i.e. in the context of the emerging multipolar power constellation outlined above, the United Nations, the World Trade Organization (WTO), the IMF, or the global climate regime will look the way they do today?

As well as challenging the content of global governance, the multipolar world will also challenge governance processes. Established consensuses will be challenged and the range of influences will be broadened. This is likely to expose the limitations of existing practices for managing conflict and reaching agreements in global governance institutions. In a multipolar world, informal mechanisms for establishing consensus (or "deals") such as the "Green Room" at the WTO will come under even more strain (Page 2004: 78). New alliances may emerge, such as the agreement between the USA, China, India, South Korea, Japan and Australia on climate change, signed on 26 July 2005. Both "East" and "West" may fracture or line up differently on different issues. From this perspective, a fragmented global governance architecture, characterised by centrifugal powers, is much more probable than an inclusive global governance structure. 
The roles that China and India will play are far from defined. They will be determined by internal processes and relationships with other countries. As rapidly growing and transforming developing societies, China and India are certainly going to have to master a number of difficult domestic adjustment processes (China's path towards political liberalisation and how to deal with growing social polarisation trends; to cite two examples). History shows that internal tensions often result in nationalistic, aggressive foreign policy strategies. Thus, given the growing political weight of China and India in global politics, the future of global governance could depend on their internal governance capacities to manage critical national transformations (Heberer and Senz 2005 forthcoming). These in turn will have ramifications for their relationships with developed and other developing countries.

\section{Challenges for developing countries}

The biggest challenges arising from the emergence of China and India surely face developing economies. First, there is the question of the rapid change in global competitive conditions as a result of the growth of China and India. Because of their high rates of economic growth, the size of their economies, and the pace of structural change in both countries, the rise of both China and increasingly India, is generating enormous adjustment pressure in other regions of the world. Following decades of declining prices for primary goods, the terms of trade for raw materials and agricultural goods have, since 2001 , been moving in the opposite direction (Kaplinsky 2005). The reason: demand pull from China and India. In a growing number of sectors, Chinese industrial exports are cutting incisively into the world-market shares of industrial companies from Latin America (Dussel 2005) and Africa. The economic dynamics in the world's two most populous countries are leading to significant changes in the world markets for labour, goods and financial flows.

As other articles in this IDS Bulletin show, the impacts of India and above all China on developing economies are very diverse, creating both winners and losers. Developing country policy-makers need to understand and respond to the new global conditions. The winners (particularly energy and raw materials exporting countries) will have to deal with the impacts of rising volumes and prices of exports, while the losers (both raw materials and energy importers facing rising prices and countries facing competition from cheap manufactured goods in both their domestic and export markets) will face difficult adjustment processes.

The emergence of India and China as development actors will have further impacts on developing countries in at least three areas. First, it might open up new development options for these countries, most notably in relation to development options. When Angola wanted a US $\$ 2$ bn loan, it wanted to avoid the IMF. It went to China instead, and in return China gained access to the Angolan oil industry (Alden 2005: 6). Such interventions may act as a counterweight to liberalisation agendas pursued by the developed countries.

Second, China and India have the capacity to engage in global governance debates and influence policy formulation, particularly in areas such as the considerations over trade issues. The increasing size and competitiveness of their economies may also create de facto standards setting power. For example, China has developed its own organic standard, the Green Food label (IFAD 2005: 9-12). Similarly, the growth of India and Chinese industrial enterprises might challenge the hegemony of Western transnationals in areas of intellectual property. This shows that they have the capacity, for example, to participate in technical negotiations around standards setting, providing an expression of the needs and priorities of developing countries, which have often been marginalised. All that might result in some advantages for other developing countries - as long as their interests and the interests of China and India coincide. But at the same time, the emergency of these two new capable global standard-setting powers implies for all the standard takers of the South additional threats to their national sovereignty.

Third, China and India may introduce countervailing power to the hegemony of the USled Bretton Woods institutions. What might be the impact of the emergence of China and India as powerful actors in global governance institutions on the voice of other developing countries? In this respect, the critical question is whether India and China will play the role of advocates in the interests of the developing countries (as India did within the G77 group of developing countries), possibly risking 
the emergence of new North-South tensions, or alternatively will pursue primarily their own interests, which need not at all coincide with the interests of the world's other developing economies?

Developing country participation within global governance institutions and the activities of lead nations has often been informed by ideologies of common interests. India has frequently presented itself as a leader of the developing world. South Africa after apartheid and Brazil (particularly since the election of Lula as president) have consciously taken up this role. The fact that India, Brazil and South Africa created in 2003 a democratic G3 of the South, not integrating China, is a signal that these countries are proactively trying to play a more prominent role as non-OECD countries in a world perceived as G7/G8 driven. They see themselves as voicing the interests of poor countries. Is this autoperception convincing? Such a role need not preclude the pursuit of self-interest. Brazil is capable of pursuing pro-poor initiatives in the UN and voicing a multilateral rhetoric, while simultaneously adopting regional policies towards Mercosur that are guided by very clear articulated economic self interests. It is too early to tell. While China and India, together with Brazil and South Africa provided effective leadership of a large group of developing countries at Cancun in 2003, this leadership (offered and accepted) may turn out to have been the exception rather than the rule.

\section{Research programme}

This brief outline is meant to illustrate the potentially far-reaching implications and trends of the rise of China and India in the hierarchy of global governance. A research programme is needed to lay bare the precise contours of the terrain of global change. The first step in a research programme would be to understand better the postures that these countries take with regard to global governance. Relevant dimensions of research and questions include:

1. Engagement in global governance areas: In which areas of global governance are the countries playing proactive roles (agenda-setting capacities; mobilising other countries, organising voting blocs, being able to build ad hoc and/or stable coalitions; spending money in international affairs; organising global conferences), and in which fields are their roles more passive? Are these roles primarily at regional level, or are they exercised on a global scale? What implications does this have for other developing countries, and how should they respond?

2. How do these countries approach international politics?: (a) expressing narrowly defined national interests; (b) actively seeking enhancement of regional leadership roles; (c) actively seeking global leadership roles within the developing country grouping; (d) identifying themselves as leading global actors, irrespective of developing countries? It seems likely that the desire for control over essential resources (raw materials and energy) will be one factor in shaping these countries' approaches to international politics. Will it be the determinant one, and what will these strategic interests and others adopted by China and India imply for other developing countries?

3. How do India and China approach the following pillars of global governance: (a) cooperative multilateralism vs. unilateralism; (b) international system based on rules of law vs. avoiding international binding rules (e.g. International Chamber of Commerce - ICC); (c) strong UN vs. weak UN; (d) regional cooperation and integration as an answer to globalisation (e.g. European Union) vs. strategies to strengthen political power of the dominant countries within the region (US-Latin America).

4. Patterns of power: Four main forms of power can be distinguished: (a) power via relations with other actors (influencing many actors by direct interaction); (b) the power of being able to organise cooperation and trust, to convince others and to be attractive for others (soft power); (c) institutional power (being able to invest in global governance institutions, regimes, standard-setting processes: influencing many by defining the rules of the game); (d) power via force/compulsion (be able to force others based on military power, political dominance, financial capabilities). Which forms of power do the 'Asian Drivers of global change' use/are they able to build up?

5. Private actors of global governance: How do these countries view and deal with the "new" private actors in world politics? (NGOs on the one hand and the business sector on the other?) To what extent are new private actors emerging from these countries, and what agendas do they have? 
More generally, how do China and India challenge the power of developed countries and their transnational companies to set the rules of international business - Intellectual Property Rights, The Agreement on Trade-Related Investment Measures (TRIMs), etc. - both within formal global governance institutions and through de facto exercises of power (e.g. the US Department of Agriculture's role as setter of pharmaceutical standards)? Will such challenges open up new opportunities for other developing countries, or pose new threats?

6. The internal politics and policy dimensions: How do the political elites in both countries perceive the increasing international importance of their country, and how is their emerging role in world politics discussed? What political consensuses exist within these countries about their positions within the region and in world politics? Are the

\section{Notes}

1. See, for example, Aninat (2002) and statements from UN organisations on the need to manage processes of globalisation.

2. Cited in Higgins and Lawrence (2005: 5).

3. See, for example, Zarrilli's analysis of the operations of the Codex Alimentarius Committee (Zarrilli 1999: 15).

4. Source: www.uscc.gov/trade_data_and_analyses/industry _job_trends/2005/B-95-05-US-X-M-share.pdf

5. Of course, Japan is a non-Western actor on the global stage, but unlike China and India, it did take on this role when it was a poor country. It can also be argued that

\section{References}

Alden, C., 2005, 'Leveraging the dragon: towards "An Africa that can say no"', eAfrica, The Electronic Journal of Governance and Innovation (accessed 1 March 2005)

Aninat, E., 2002, 'Surmounting the challenges of globalisation', Finance \& Development, Vol 39 No 1, www.imf.org/external/pubs/ft/fandd/2002/ 03/aninat.htm (accessed June 2005)

Cooper, R., 2003, The Breaking of Nations, Order and Chaos in the Twenty-first Century, New York: Grove Press

Daalder, I.V. and Lindsay, J.M., 2004, America Unbound, Washington, D.C.: Brookings Institution Press

Deutsche Bank Research, 2005, India Rising. A Medium Term Perspective, www.dbresearch.com (accessed October 2005) currently guiding approaches dominating in China and India about their roles as 'Actors of Global Change' fixed or in transition?

7. The internal polity dimension: To be an active and influential global governance player (a) effective institutional capacities (ministry of foreign affairs and other internationally oriented ministries); (b) strategic capabilities of the diplomatic corps (global governance school, training of diplomats) and (c) investments in the research of international affairs, globalisation processes, etc. in order to create "soft power capacities" (universities, think-tanks, publications in this field) are needed. Are there differences in the ways that China and India are preparing to play a significant role in these fields, and how will their interests and strategies impact upon other developing countries?

Japan's economic weight has not, until recently, been turned into political clout. Japan has tended to be a timid and hesitant political actor, unlike China, and increasingly India.

6. A report in the China Daily emphasises China's confidence: 'Chinese President Hu Jintao said in no uncertain terms last week to the United Nations General Assembly that China's rise is a blessing to its neighbours and major trade powers, is a force of peace for Asia and the world, and will "not endanger anybody". Hu spoke out a package of aid programmes to help the world's remaining impoverished countries, Africans especially' (23 September 2005).

Dussel, E., 2005, Economic Opportunities and Challenges Posed by China for México and Central America, Bonn, German Development Institute

Friedman, T.L., 2005, The World is Flat. A Brief History of the Twenty-first Century, New York: Farrar, Straus and Giroux

Goldman Sachs, 2003, 'Dreaming with BRICs. The path to 2050', Global Economics Paper 99, www.gs.com/insight/research/reports/report6.html (accessed September 2005)

Heberer, T. and Senz, A.D., 2005 forthcoming, 'Die rolle Chinas in der globalen strukturpolitik', DIE Discussion Paper, Bonn: German Development Institute

Higgins, V. and Lawrence, G., 2005, 'Globalisation and Agricultural Governance', in V. Higgins (ed.), Agricultural Governance: Globalisation and the New Politics of Regulation, London: Routledge: 1-15 
IFAD, 2005, Organic Agriculture and Poverty Reduction in Asia: China and India Focus, Final Draft, Rome, International Fund for Agricultural Development, www.ifad.org/evaluation/public_html/ eksyst/ doc/thematic/organic (accessed May 2005)

Kagan, R., 2003, Paradise and Power. America Versus Europe in the Twenty-first Century, New York: Alfred A. Knopf

Kaplinsky, R., 2005, 'Revisiting the revisited terms of trade. Will China make a difference?', unpublished paper, Brighton: Institute of Development Studies

Kennedy, P., Messner, D. and Nuscheler F., 2002, Global Trends and Global Governance, London: Pluto Press

Kupchan, C., 2002, The End of the American Era, New York: Alfred A. Knopf

Kurlantzick, J., 2005, 'China's chance', Prospect, March

Maggi, C. and Messner, D. (eds), 2002, Gobernanza Global. Una Mirada Desde América Latina, Caracas: Nueva Sociedad

Mead, W.R., 2004, Power, Terror, Peace, and WarAmerica's Grand Strategy in a World at Risk, New York: Alfred A. Knopf

Messner, D., 2000, 'Ist Außenpolitik noch Außenpolitik ... und was ist eigentlich Innenpolitik. Einige Beobachtungen zur Transformation der Politik in der Ära des Globalismus', PROKLA. Zeitschrift für Kritische Sozialwissenschaft, Vol 30 No 118: 123-51

Nadvi, K. and Wältring, F., 2004, 'Making Sense of Global Standards', in H. Schmitz (ed.), Local Enterprises in the Global Economy, Cheltenham: Edward Elgar: 53-94
Nye, J.S. and Donahue, J.D., 2000, Governing in a Globalizing World, Washington, D.C.: Brookings Institutional Press

Page, S., 2004, 'Developing countries in international negotiations: how they influence trade and climate change negotiations', IDS Bulletin, Vol 35 No 1: 71-80

Ramo, J., 2005, The Beijing Consensus, London: Foreign Policy Centre

Rodrik, D., 1997, Has Globalization Gone Too Far?, Washington, D.C.: Institute for International Economics

Rodrik, D. and Subramanian, A., 2004, 'Why India can grow at 7 per cent a year or more: projections and reflections', IMF Working Paper 04/118, New York: International Monetary Fund

Rosenau, J.N., 1997, Along the Domestic-Foreign Frontiers, Cambridge: Cambridge University Press

Scholte, A., 2000, Globalization: A Critical Introduction, Basingstoke: Palgrave

Stamm, A., 2004, 'Schwellen- und Ankerländer als Akteure Einer Globalen Partnerschaft', DIE Discussion Paper 1, Bonn: German Development Institute

World Bank, 2002, 'Globalisation, growth, and poverty', Policy Research Report, Washington, D.C.: World Bank, econ.worldbank.org/prr/ globalization/text-2857 (accessed February 2004)

Zarrilli, S., 1999, 'WTO sanitary and phytosanitary agreement: issues for developing countries', TRADE Working Papers 3, Geneva: South Centre

Zürn, M., 1998, Regieren Jenseits des Nationalstaates, Frankfurt: Suhrkamp Verlag 